Review

\title{
Multifunctional Urban Agriculture for Sustainable Land Use Planning in the United States
}

\author{
Sarah Taylor Lovell \\ Department of Crop Sciences, University of Illinois, 1201 Dorner Drive, Urbana, IL 61801, USA; \\ E-Mail: stlovell@illinois.edu; Tel.: +1-217-244-3433; Fax: +1-217-244-3469
}

Received: 11 June 2010; in revised form: 1 July 2010 / Accepted: 4 August 2010 /

Published: 4 August 2010

\begin{abstract}
Urban agriculture offers an alternative land use for integrating multiple functions in densely populated areas. While urban agriculture has historically been an important element of cities in many developing countries, recent concerns about economic and food security have resulted in a growing movement to produce food in cities of developed countries including the United States. In these regions, urban agriculture offers a new frontier for land use planners and landscape designers to become involved in the development and transformation of cities to support community farms, allotment gardens, rooftop gardening, edible landscaping, urban forests, and other productive features of the urban environment. Despite the growing interest in urban agriculture, urban planners and landscape designers are often ill-equipped to integrate food-systems thinking into future plans for cities. The challenge (and opportunity) is to design urban agriculture spaces to be multifunctional, matching the specific needs and preferences of local residents, while also protecting the environment. This paper provides a review of the literature on urban agriculture as it applies to land use planning in the United States. The background includes a brief historical perspective of urban agriculture around the world, as well as more recent examples in the United States. Land use applications are considered for multiple scales, from efforts that consider an entire city, to those that impact a single building or garden. Barriers and constraints to urban agriculture are discussed, followed by research opportunities and methodological approaches that might be used to address them. This work has implications for urban planners, landscape designers, and extension agents, as opportunities to integrate urban agriculture into the fabric of our cities expand.
\end{abstract}


Keywords: multifunctional landscape; ecosystem services; food systems; sustainable development; urban agriculture

\section{Introduction}

In the introduction to this Special Issue on Land Use and Sustainability, guest editor Brian Deal poses the question: "What are the approaches, methods and tools needed to shape the development of human habitats and ensure their sustainability into an uncertain future?" This review of the literature on urban agriculture offers a strong argument that one answer to this question can be found in the intentional integration of multifunctional agriculture into city planning. Urban agriculture has been defined as "... the growing, processing, and distribution of food and nonfood plant and tree crops and the raising of livestock, directly for the urban market, both within and on the fringe of an urban area" ([1]; p. 4). These agricultural activities take many forms and occur at multiple scales in cities throughout the world, responding to the needs and preferences of urban residents. In the U.S., however, agriculture is typically considered to be a land use activity associated with the rural landscape, where vast areas of farmland can support large-scale production systems. However, growing evidence suggests that incorporating appropriate types of agriculture into the urban environment will greatly improve the sustainability of U.S. cities, particularly if these systems are designed to take advantage of the resources and markets available there [2,3]. In fact, urban agriculture rarely competes directly with rural agriculture, but instead offers products and functions that are compatible across the region. Mougeot (2006) suggests that "...the very close connection in space that the US entertains with the ecology and economy of cities makes this very distinct from but complementary to rural agriculture" ([1]; p. 5).

Because of the high value of land and many competing land use needs in cities, agriculture may not initially seem like a wise alternative for urban settings. In fact, certain production systems would be completely inappropriate for this environment, such as those requiring large tracts of land, relying heavily on inputs of petrochemicals, or creating negative externalities for the surrounding environment (e.g., conventional grain production or livestock confinement systems). For an urban environment, agricultural production systems that take advantage of the close proximity of resources and consumers, such as those offering fresh, value-added, specialty products would be most appropriate. Systems providing food that can be directly consumed by nearby residents could offer many benefits for growers, consumers, and the community. However, even with these systems, justifying the use of urban land for agriculture based on the production functions alone can be a challenge. Instead, urban agriculture should be evaluated based on a framework of landscape multifunctionality, which accounts for the many services or benefits that can be provided by agricultural land uses. In addition to production functions, urban agriculture offers a wide range of ecological functions (e.g., biodiversity, nutrient cycling, and micro-climate control) and cultural functions (e.g., recreation, cultural heritage, and visual quality) that benefit the nearby community and society as a whole [4].

Historical examples of agriculture from around the world would suggest that as a land use, agriculture is inherently multifunctional, offering a number of public benefits beyond the provision of 
commodity outputs [5,6]. However, the industrialization of agriculture, particularly in the U.S. and other developed countries, has resulted in landscapes that are strongly production-oriented, often neglecting the cultural and ecological functions that had previously been supported by agricultural activities [7]. As a result, Americans often overlook the enormous benefits that agriculture could provide, if these systems were designed for multifunctionality [8]. A transition of agriculture to strong multifunctionality should be the desired outcome with the greatest benefits for society [9]. Urban and peri-urban farms offer unique potential for strong multifunctionality [10], and their location near dense population centers could improve the successful transfer of benefits from these agricultural activities [11,12]. The real challenge is to design our urban landscapes for a wide range of functions, based on the specific context of the site [13,14], while exploring synergies and focusing on positive externalities that benefit the urban society $[6,15,16]$. In addition, the intentional establishment of physical linkages and cultural connections between urban agriculture and rural agriculture could provide positive outcomes beyond the limits of the city [17].

The most obvious benefits of urban agriculture are related to the production of foods in close proximity to the consumers. The availability of fresh fruits, vegetables, and other foods for urban residents should not be underestimated, particularly in communities and neighborhoods where grocery stores and markets have moved out, leaving a "food desert" [18]. In some cases, the food is consumed directly by the producer, improving the food security (access to healthy and culturally acceptable food) for the household [19]. In other cases, much of the food is sold through local markets, providing income for individual residents and economic vitality for the community [11,20,21]. Urban agriculture activities are broad and diverse and can include the cultivation of vegetables, medicinal plants, spices, mushrooms, fruit trees, and other productive plants, as well as the keeping of livestock for eggs, milk, meat, wool, or other products [22]. By using intensive production strategies and focusing on high value crops, the economic value of urban agriculture systems can be substantial. An urban farm in Milwaukee, Wisconsin, for example, grosses more than $\$ 200,000$ per acre (0.405 hectares) [23].

For the greater public, the ecological functions and environmental benefits of urban agriculture often outweigh the production functions. By producing food locally and balancing production with consumption, the embodied energy of the food required to feed the cities is reduced because of lower transportation distance, less packaging and processing, and greater efficiency in the production inputs [24]. The reduced energy requirements could in turn decrease greenhouse gas emissions and global warming impacts compared with conventional food systems [2]. Energy is also conserved by reusing urban waste products locally, both biodegradable wastes for compost, and waste-water (e.g., stormwater and greywater) for irrigation [25,26]. The reuse of wastes offers another benefit in reducing transportation and land use requirements for disposal and long-term management [27], essentially closing the loop in the cycle of waste resources [26]. Urban agriculture, like urban gardens, can also contribute to biodiversity conservation, particularly when native species are integrated into the system [28]. These systems can offer additional ecological benefits in modifying the urban micro-climate by regulating humidity, reducing wind, and providing shade [2].

Compared with rural agriculture, the integration of urban agriculture into densely populated areas greatly extends the opportunities for combining food production with cultural functions on urban green space [29]. In situations where food production occurs on vacant lots or other derelict land, the effect of greening the neighborhood alone is a positive outcome for all residents in terms of visual quality 
and human health and well-being [30,31]. The entire community also benefits from the creation of new jobs for residents who struggle to find work [27], from opportunities to socialize and cooperate with friends and family [26], and from the environmental awareness that comes from a connection to an agroecological system [2,32]. By improving access to fresh, nutritious food, urban agriculture can help in combating childhood obesity, diabetes, and poor nutrition that are prevalent in many urban communities [3]. Residents participating in community gardens and school gardens have healthier diets, consuming more fruits and vegetables than non-participants [33,34]. Urban agriculture can also be very effective in providing a community with access to rare foods that support their cultural heritage, particularly for immigrant communities [35]. Studies have demonstrated additional social benefits of community gardens through their role in improving interracial relationships and decreasing crime [36,37]. Beyond the benefits for the community, individuals participating directly in the production of food enjoy the recreation and relaxation of gardening outdoors $[20,35]$. They feel more empowered as they improve the food security of the household and gain new knowledge and technical skills [38]. In fact, in school gardens and other community programs, the educational component can extend beyond production to include knowledge development in cooking, nutrition, science, environment, business management, and cultural sensitivity or understanding [39-41].

Despite the enormous benefits for individuals and communities, urban agriculture is largely ignored in urban and regional planning $[42,43]$. Instead of considering opportunities to preserve farmland or to integrate new production functions into urban environments, agricultural landscapes are often considered by land use planners as areas for future development [44]. Because planners and policymakers are not typically engaged in the production activities of agriculture, they often overlook problems and opportunities within the entire food system [45]. As a result, we see a growing disconnect between urban residents and the agricultural landscapes that sustain them [46]. Further exacerbating the problem is the globalized economy, which encourages the importation of food from distance sources [47]. While this approach has not threatened the availability of food for most communities in the United States (at least in terms of quantity), the increased consolidation of food systems activities, along with the concentration of agricultural land ownership, takes control away from local communities and threatens food security in the future. A community dependent on food resources from distant locations is vulnerable to any unforeseen disasters (natural or otherwise) or disruptions at different levels of the food systems chain from production through processing and transport to distribution centers.

By neglecting activities related to food systems, planners are missing a great opportunity to use something as essential and enjoyable as food, in their efforts to develop healthy communities that support a good quality of life [42]. Food, as one of the basic essentials of life, has been almost completely avoided as an organizing strategy for improving communities [47]. For example, rarely are urban agriculture features such as community gardens given the same level of importance as other open green space, and the result has been a lack of inclusion in the city planning process or zoning to protect them [48]. Urban areas often require the greatest effort, but also offer the greatest potential reward in the integration of local food systems in planning, primarily because of the high densities of consumers and large proportion of poor living in cities [29]. Planners, because of their large-scale perspective, could play an important role in designing urban areas to include community gardens and other urban agriculture features, protecting these features through appropriate zoning $[43,48]$, and even 
regulating the number (or area) required per capita [45]. Urban planners could also consider farmers markets', farm-to-institution programs, and local food networks to connect growers with processors, restaurants, groceries, and direct to consumer purchasing. Transportation systems to distribute food and waste, considering accessibility by residents, are also an urban planning opportunity [45]. In many ways, urban planners are uniquely positioned to coordinate activities across fields, allowing urban agriculture to live up to its full potential as a multifunctional and sustainable land use. In Table 1, specific planning strategies are proposed for supporting the various functions that are offered by urban agriculture activities.

Table 1. Urban planning to support various functions of urban agriculture.

\begin{tabular}{|c|c|c|}
\hline Function & Description and Justification & Supportive Planning Strategies \\
\hline Production & $\begin{array}{l}\text { Urban agriculture produces fruits, vegetables, } \\
\text { mushrooms, herbs, medicinal plants, meats, } \\
\text { milk, cheese, eggs, and other products. }\end{array}$ & $\begin{array}{l}\text { Provide suitable, accessible, and safe land } \\
\text { with good solar access and an irrigation } \\
\text { source. }\end{array}$ \\
\hline $\begin{array}{l}\text { Energy } \\
\text { Conservation }\end{array}$ & $\begin{array}{l}\text { Producing food locally reduces the embodied } \\
\text { energy resulting from inputs, transport, and } \\
\text { packaging. }\end{array}$ & $\begin{array}{l}\text { Develop transportation systems and } \\
\text { networks to efficiently get food to } \\
\text { consumers. }\end{array}$ \\
\hline $\begin{array}{l}\text { Waste } \\
\text { Management }\end{array}$ & $\begin{array}{l}\text { Organic waste products can be composted } \\
\text { and used as a fertility resource for growing } \\
\text { food and other products. }\end{array}$ & $\begin{array}{l}\text { Identify systems to collect, divert, and } \\
\text { transport organic wastes away from } \\
\text { landfills to urban agriculture. }\end{array}$ \\
\hline Biodiversity & $\begin{array}{l}\text { Agricultural systems can support a wide } \\
\text { range of species, including some native } \\
\text { plants, as crops or associated plants. }\end{array}$ & $\begin{array}{l}\text { Convert some open space areas of low } \\
\text { diversity (i.e., turf) to community gardens } \\
\text { and farms. }\end{array}$ \\
\hline $\begin{array}{l}\text { Microclimate } \\
\text { Control }\end{array}$ & $\begin{array}{l}\text { Urban agriculture can positively alter } \\
\text { microclimate through humidity control, wind } \\
\text { protection, and shade. }\end{array}$ & $\begin{array}{l}\text { Allow edible plantings in built areas to } \\
\text { combat the heat island effect and other } \\
\text { unfavorable climatic conditions. }\end{array}$ \\
\hline Urban Greening & $\begin{array}{l}\text { Community and backyard gardens contribute } \\
\text { to the greening of urban areas, improving } \\
\text { aesthetics and well-being. }\end{array}$ & $\begin{array}{l}\text { Support efforts to convert vacant and } \\
\text { derelict lands into productive green spaces } \\
\text { for use by residents. }\end{array}$ \\
\hline $\begin{array}{l}\text { Economic } \\
\text { Revitalization }\end{array}$ & $\begin{array}{l}\text { Urban agriculture ventures offer new jobs for } \\
\text { neighborhood residents and vitality from } \\
\text { improved economics of the community. }\end{array}$ & $\begin{array}{l}\text { Create networks to connect laborers, } \\
\text { farmers, and markets to help retain and } \\
\text { grow new ventures. }\end{array}$ \\
\hline $\begin{array}{l}\text { Community } \\
\text { Socialization }\end{array}$ & $\begin{array}{l}\text { Community members often find gardening } \\
\text { and farming to be a social activity through } \\
\text { sharing food, knowledge, and labor. }\end{array}$ & $\begin{array}{l}\text { Along with community garden spaces, } \\
\text { integrate other activities and features to } \\
\text { encourage socializing. }\end{array}$ \\
\hline Human Health & $\begin{array}{l}\text { In addition to the known benefits of access to } \\
\text { green space, urban agriculture offers healthy } \\
\text { food and encourages physical activity. }\end{array}$ & $\begin{array}{l}\text { Explore opportunities to develop } \\
\text { community programming around } \\
\text { gardening/farming as a healthy lifestyle. }\end{array}$ \\
\hline $\begin{array}{l}\text { Cultural } \\
\text { Heritage }\end{array}$ & $\begin{array}{l}\text { Urban agriculture can provide access to rare } \\
\text { ethnic foods that are typically not available in } \\
\text { existing markets. }\end{array}$ & $\begin{array}{l}\text { Integrate community garden spaces in areas } \\
\text { known to have high immigrant populations, } \\
\text { and link with culture. }\end{array}$ \\
\hline Education & $\begin{array}{l}\text { Children and adults learn about foods, } \\
\text { nutrition, cooking, environment, economics, } \\
\text { and cultures through urban agriculture. }\end{array}$ & $\begin{array}{l}\text { Offer gardening and urban agriculture } \\
\text { activities within existing programs, } \\
\text { particularly during summer. }\end{array}$ \\
\hline
\end{tabular}




\section{International Precedents}

Urban agriculture has existed as long as there have been cities, often evolving as a necessary option for improving food security and supporting the livelihoods of urban residents [1,49]. Throughout history and around the world, urban agriculture has taken many different forms depending on the climate, available technologies, and cultural preferences. For thousands of years, homegardens have been cultivated in the cities of developing countries to provide food for urban residents through multistory combinations of trees, shrubs, and herbaceous plants [32,50]. These specialized agroforestry systems support high levels of biodiversity and provide a large number of products [51,52]. During the Middle Ages, kitchen gardens became popular throughout Europe for growing vegetables, fruits, medicinal herbs, and cut flowers primarily for the residents of the household [53]. On a larger scale, Machu Picchu is an example of a 16th century city constructed physically to support food production, including critical infrastructure such as terraces and irrigation, as well as management systems for waste, microclimate control, and food storage [54].

Across the globe, urban agriculture systems have evolved to meet the needs of residents in contemporary cities. Many specific examples have been documented, mostly in developing regions such as sub-Saharan Africa, Latin America, and Southeast Asia [1,19,55]. In these regions, the focus is often on improving the livelihoods of the poor in urban areas by providing food for consumption, reducing costs associated with food [56], diversifying activities for producing income [17], and empowering women [50,57]. Urban agriculture can also be an effective strategy for responding to a crisis. The most impressive example of urban agriculture in recent years comes from Havana, Cuba, following the collapse of the Soviet Union, which ended the extensive trade between the countries [58]. Havana suffered from the loss of earnings from their exports (esp. sugarcane), as well as from the lost imports of petrochemicals, machinery, and imported food [30,58]. From 1997 to 2003, Havana experienced an average of $38 \%$ growth in urban agriculture annually, resulting in a 13-times increase in the production of vegetables over the 8-year period. Much of the production has taken place in "organoponicos", which are raised beds with a mix of soil and organic matter that can be constructed on almost any plot of land. Today, much of the available land has been transformed into urban agriculture, totaling more than 35,000 ha within the boundaries of Havana (including urban fringes and nearby rural areas) [30].

Many cities in developed countries have also recognized the extensive benefits of urban agriculture, and planning or policy strategies have been developed to support food production within the city boundaries, including a strong emphasis on the social functions provided by urban agriculture. Montreal, for example, has a well-distributed urban agriculture system with 97 community gardens that provide 8,200 separate plots. These garden spaces have been recognized for their contributions to community socializing, empowerment of individuals, and enhancing technical knowledge [38]. In Beijing, multifunctional urban agriculture is a new trend for producing food, and as a result, organic diversified farms [59] and extensive greenhouses have emerged throughout the city [60]. In Shanghai, China, considered to be the city where urban agriculture originated, many productive lands are retained for the specific purpose of growing food [60]. Urban agriculture activities within the city supply $60 \%$ of the vegetables and $90 \%$ of the eggs consumed by the residents [22]. The Terrassa municipality of the Metropolitan Region of Barcelona contains over 1,200 garden plots covering $0.65 \%$ of the land 
area. Although many of these sites are occupied illegally, they supply a large percentage of the household vegetable needs for the gardeners [61]. In the Netherlands, 250,000 community and allotment gardens exist across 4,000 ha of land, and Amsterdam alone contains 350 ha of land for urban gardens [62]. Clearly, urban agriculture continues to be an extensive and important activity in regions across the world.

\section{History of Urban Agriculture in the U.S.}

In the U.S., the history of urban agriculture dates back more than a century. Community garden expert, Dr. Laura Lawson, documented the early history of these functional urban spaces in her book, City Bountiful: A Century of Community Gardening in America. In the 1890's, community gardens were emerging on vacant lots in the cities such as Detroit, New York, and Philadelphia, to provide food for nearby residents. During the Great Depression (1930's), some city residents dealt with the problems of the time by producing their own food in urban garden plots and gaining employment through jobs created on city farms. The 1940's brought new issues, with World War II and the subsequent rationing of food. As a result, victory gardens (including both backyard gardens and allotments on public spaces) were promoted by the federal government and other public agencies. In the 1970's, many new community gardens were developed to support the renewal of urban areas - offering food, recreation, and social benefits to help revitalize communities [63]. Since that time, the urban agriculture movement has been expanding in many cities, often beginning as simple grass-roots efforts in individual neighborhoods that later evolve into larger, coordinated programs. New York City's GreenThumb, for example, has become the "largest community gardening program in the country", with more than 600 gardens that support 20,000 urban residents (http://www.greenthumbnyc.org/).

Much of the interest in urban agriculture in the U.S. today focuses on opportunities to improve food security, or access to healthy, culturally appropriate food [21]. Many of our cities have extensive areas that are considered to be "food deserts", not particularly due to a complete lack of available food, but rather because the stores stock only processed foods and do not offer fresh fruits and vegetables. Furthermore, where fresh food is available, many individuals living in poverty cannot afford the higher prices of fresh compared with processed food [21]. Urban agriculture is viewed as an opportunity for individuals to gain access to healthy food and even participate in the process of growing it themselves. Along with food security, another driver of urban agriculture is the growing interest in a localized food system [19] and the related opportunities to improve the sustainability of the system through waste recycling, stormwater management and reuse, reduced energy requirements for food transport and storage, and other benefits. Urban agriculture in the U.S. has also been expanded and enriched by the influx of immigrants from other countries into our cities. The potential to retain cultural heritage through ethnic foods, specialized agricultural practices, and social space, cannot be overlooked [21].

With the growing interest in urban agriculture in the U.S., the American Planning Association (APA) has recently recognized the importance of integrating food systems into land use planning. APA general policies related to food systems focus on opportunities to support comprehensive food planning processes at the community and regional levels and to strengthen local and regional economies by promoting food systems. According to the guidelines, planners should seek to support (through policies and legislation) food systems that improve residents' health, increase sustainability of 
the environment, and reflect cultural heritage of ethnic minority communities [47]. While the importance of food systems in planning has been recognized, very little research has been done to model land use alternatives based on local food systems, assess the impacts of these alternatives on the environment and local communities, or engage underrepresented minorities in the planning process.

\section{Land Use Applications at Multiple Scales}

"Edible landscapes can be included as strategic, sustainable, and multifunctional components of statutory municipal plans, urban design schemes, neighborhood development projects, urban upgrading initiatives, and the design of housing" [22]. Indeed, edible landscapes and urban agriculture can be designed in many different forms and at many different scales, to provide an enormous range of benefits for urban residents.

\subsection{Entire Cities}

A visionary proposal by architect Andre Viljoen and colleagues is to integrate Continuous Productive Urban Landscapes (CPULs) as an urban design strategy [64]. CPULs are described as "...open landscapes productive in economical and sociological and environmental terms". The idea is to develop networks of open space running continuously throughout the city and finally connecting to the rural area. These spaces would be "productive" in that they would offer space for growing food [24]. The productive spaces would be very intentionally integrated with other functions including recreation and visual quality, to improve the overall character of the urban environment, similar to a greenway network. While the concept is somewhat theoretical, since it has not been directly applied in the planning of new cities, this type of approach has the potential to inspire efforts to retrofit urban agriculture within the existing fabric of a city.

A number of examples exist where urban agriculture has been used as a guiding theme for transforming a city, and some of these were described in the previous section on International Precedents (e.g., Havana, Cuba). Several U.S. cities also have extensive planning efforts underway to support urban agriculture. Portland, OR, has the benefit of a strong food culture and an urban population consisting of many residents interested in sustainability-both of which contribute to the growth in urban agriculture (Figure 1). At the city level, the interest in urban agriculture is exemplified by the establishment of a Food Policy Council in 2002, which supported the "Diggable City" project to assess the suitability of public land for different forms of urban agriculture [65]. Philadelphia is host to a growing number of new urban farms, and agriculture is an integral part of the curriculum in several urban schools. The well-established "Philadelphia Green" program, which has been promoting green infrastructure in the city for more than 30 years, has recently been investing more resources in urban agriculture [3]. In Chicago, urban agriculture is being explored as a solution to issues of food insecurity and limited access to good jobs in some low-income neighborhoods. Urban agriculture could offer healthy food, sustainable jobs, and a greater awareness about the ecology of food systems [66]. 
Figure 1. Urban agriculture in Portland, OR. (a) Descriptive narrative of Portland's initiatives. (b) Zenger Farm in July 2009. (c) Sign providing a map and description of sustainable approaches at Zenger Farm. (d) Boyles Community Garden in July 2009.

(a) Portland, OR, a city recognized for innovation in sustainable development and planning, has been building a local food system that increasingly supports urban agriculture. The popular Edible Portland magazine, for example, regularly includes articles and information on farmers' markets, community gardens, urban farming operations, and related topics. The City of Portland provides public space for urban agriculture on numerous community gardens and at the Zenger Farm, a historic dairy farm that has been converted into a non-profit sustainable agriculture operation. Zenger Farm has a mission to educate children and adults about urban farming and sustainability through field trips, summer camps, and workshops to promote agriculture and gardening. Portland offers 32 community gardens located throughout the city, mostly in an allotment style, where participants pay an annual fee for a plot. In 2009, the rate for a full plot $\left(20^{\prime} \times 20^{\prime}\right)$ was $\$ 75$, and raised beds were available at $\$ 20$. Residents of Portland can easily find a community garden near their home, by visiting the online Community Gardens Location Map, available through the Parks \& Recreation site.
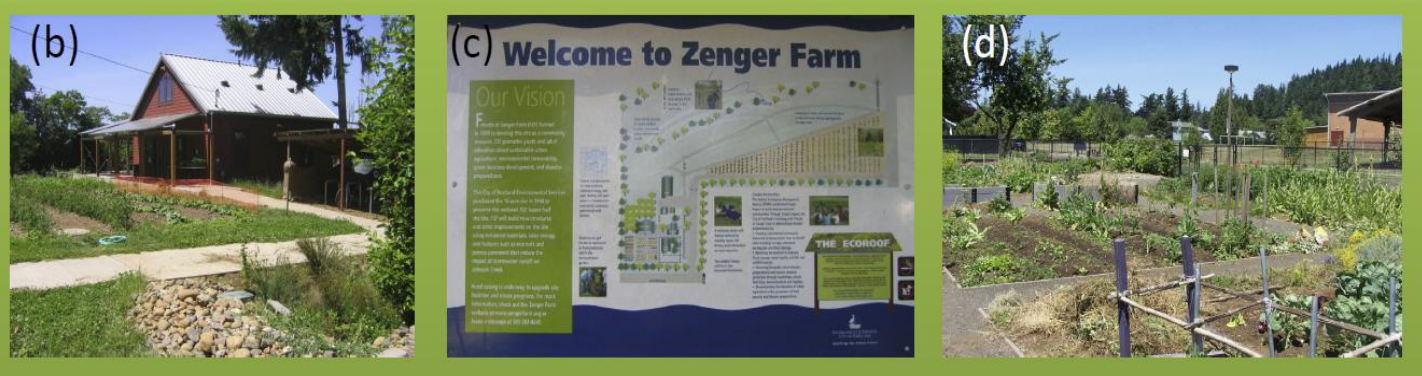

\subsection{Urban Neighborhoods}

The scale of a neighborhood can be very effective for land use planning and design to incorporate sustainable principles [67]. "Smart Growth" is an approach that encourages the integration of mixed land uses, so that many of the needs of the community might be met within a walkable distance. This could include urban agriculture ventures which would offer fresh food that could be directly consumed by residents of the neighborhood (www.smartgrowth.org). Gar House offers the prospect of "retrofitting suburban landscapes with sustainable agroecosystems", or turning oversized suburban lawns that were once agricultural land back into productive spaces, using an ecosystem approach. By cultivating some of the land, humans could reconnect with the natural environment. Subdivisions could be designed with clustered housing, walkable neighborhoods, and designated agricultural zones [68]. Notable examples of intentional communities using agriculture as a primary basis for design and planning have been established in the U.S., primarily in peri-urban areas such as Prairie Crossing in Grayslake, IL (www.prairiecrossing.com) and EcoVillage in Ithaca, NY (http://ecovillageithaca.org). A truly urban example can be found in Paseo Boricua, a low-income Puerto Rican community located in the Humboldt Park neighborhood of Chicago, well-known for its holistic approach to community development, learning, and research. (www.pedroalbizucamposhs.org/urban-agriculture/) Paseo Boricua represents a burgeoning urban agriculture effort that emerged when the youth of the community were challenged by their mentors and teachers to develop alternatives to combat community health problems ranging from obesity, diabetes, and heart disease, to gang violence and youth apathy. Several early accomplishments of this effort include: the completion of a detailed report 
on "The Greening of a Food Desert", the commitment of approximately one acre of land in Humboldt Park to serve as a food garden by the Chicago Park District, and the awarding of numerous grants including one from the McCarthey Foundation to support problem-based learning through urban agriculture [69].

\subsection{Public and Institutional Green Spaces}

Within most urban neighborhoods exist tracts of public or community green space that offer a great opportunity for establishing urban agriculture as part of the green infrastructure [4]. Parks, schoolyards, cemeteries, churchyards, and roadside right-of-ways (ROW's) might be considered for space to support food production. This public green space can be particularly appropriate for multifunctional urban agriculture, including cultural benefits, when education is considered as part of the programming of the site. Even small changes such as replacing street trees with productive fruiting species, establishing a small orchard in a park, incorporating herbs and vegetables into planters, or creating a hedge of fruiting shrubs, will have a large impact when urban residents can learn about the connection between the food they eat and the landscape on which it is produced. Urban agriculture can also be connected with ecological functions such as stormwater management, when edible species as are included in raingardens.

A larger commitment to urban agriculture would be the establishment of community gardens in public green space. Community gardens offer many benefits including neighborhood revitalization, perceptions of lower crime in the area, and community interaction through sharing of gardening skills among neighbors [70]. The city of Seattle has taken advantage of these benefits, establishing a coordinated P-Patch Community Gardens program through a Trust, to provide gardening space for residents throughout the city [48]. Community gardens can be particularly important for immigrants in the U.S., offering a space to reflect their cultural heritage and landscape memories [71,72]. For example, immigrant farmers from Southeast Asia created "homegardens" in a Florida neighborhood, where they could grow Asian herbs, fruits, and vegetables for their own consumption and to fill special economic niche [73]. Even with the benefits, in the U.S., urban agriculture features such as community gardens are not always valued at the same level as other open green space. As a result, few cities include community gardens in their city planning process, and fewer still protect these features through zoning [48]. Instead, many community gardens are established on vacant lots without permission of the landowner, and long term tenure is very uncertain. The Intervale Farm in Burlington, VT, offers an example of a mechanism for supporting community gardens and collectively-managed farms, through an incubator program whereby farmers/gardeners gain access to suitable land, shared machinery, and farmer mentors (Figure 2).

\subsection{Private Parcels}

Private parcels within the boundaries of the city can support a number of different urban agriculture activities ranging from highly profitable entrepreneurial farms to small backyard vegetable gardens. Urban or peri-urban market gardens (small farms producing high-value crops) are well-positioned to match the specific markets of the local community, alleviating the need to transport products over long distances [74]. Specific strategies that farmers might employ to retain a viable agricultural operation 
include: acquiring additional land to expand production, intensifying production with an increase in alternative high-value crops, stacking value-added products on top of the existing operation, or establishing new enterprises to complement the farm operation [75]. Market gardening can provide an important source of income, while also offering an alternative lifestyle for urban residents wanting to spend time outdoors and use their hands for labor [74]. An adaptation of the market garden approach, Small Plot INtensive (SPIN), involves farming on sub-acre plots with low equipment inputs and intensive production of high value crops. The strategy can provide over $\$ 100,000$ per acre in gross sales [76]. Some market garden businesses have transitioned to a Community Supported Agriculture (CSA) model, whereby consumers purchase "shares" that typically consist of a box of produce or other products available weekly throughout the growing season. This allows the consumers to connect directly with the farmer and to share the risks involved in maintaining an agricultural operation.

Figure 2. The Intervale in Burlington, VT. (a) In the words of farmer, S'ra DeSantis of the collectively-managed Digger's Mirth Farm. (b) S'ra carrying containers from the storage structure to the field. (c) Digger's Mirth field of vegetables. (d) Farm machinery shared by incubator farms at the Intervale.

(a) "As farmer in the Intervale, I know how fortunate I am to have a market base within miles of the farm's production center, and the community appreciates that they can come down to the farm to see our operation. Not only is the Intervale helping Burlington to become more food self-sufficient, the city does not have to rely on agricultural products that require larges amounts of fossil fuels for transportation. The Intervale also supports the community in other ways through education, food donation, and recreation. Throughout the season we host school groups - all ages from nursery schools to university classes visit our farm to learn about where their food comes from. The kids and adults usually leave the farm with smiles on their faces, dirt on their shoes, and fresh produce in their arms. Often children are bringing vegetables home that their families have never eaten. We also take part in a gleaning program, where volunteers come down to our farm each week to harvest vegetables that we were unable to sell. Then this produce gets donated to 10 social service organizations within the area including the Food Shelf, homeless shelters, and Women Helping Battered Women. ...Being part of the Intervale makes me feel like I am connected to the community." - S'ra DeSantis, Digger's Mirth Farm

(b)

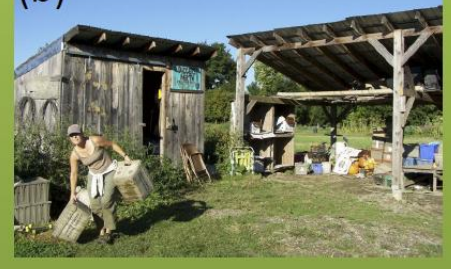

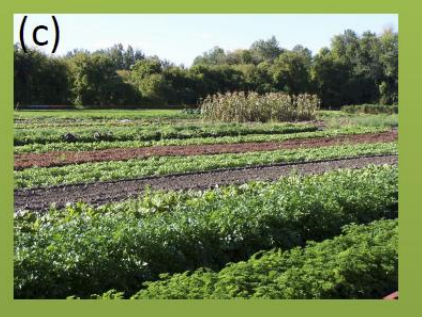

(d)

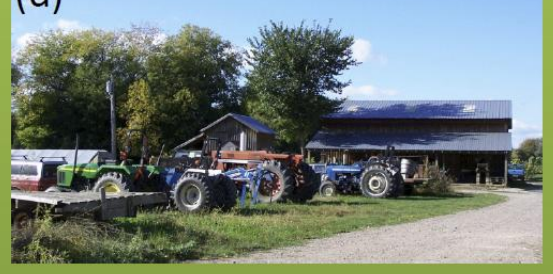

Residential yards can also be used for food production, typically for direct consumption by the household or for sharing with neighbors and friends. Backyard vegetable gardens, which have been a common element of urban yards for centuries, are regaining popularity in U.S. cities with the growing publicity about the importance of fresh, healthy food. This trend has expanded to include the visible portion of the yard (i.e., the front yard), through "edible landscaping". Several good resources are available to assist homeowners in designing residential spaces to be productive and beautiful. Landscaping with Fruits and Vegetables, by landscape architect Fred Hagy, offers practical guidelines for edible landscaping including information on site analysis, site design, plant selection, and maintenance considering both production and visual quality of the landscape [77]. Horticulture expert, Dr. Lee Reich, recently published Landscaping with Fruit, a book exploring opportunities to 
incorporate edible fruiting trees, shrubs, and herbaceous plants into the design of the residential landscape. The list of books and other resources on the topic is growing rapidly, reflecting the general interests of the public [78-80].

In Portland, OR, a new land management approach has emerged, utilizing the available land resources on residential lots to grow food for profit. Several entrepreneurs have established businesses using other landowners' property, an approach that has been termed "small-scale sharecropping" [80]. Often, the landowners donate the unused space in exchange for produce, and the excess is sold through a CSA or at a farmers' market $[81,82]$. In one case, an urban farmer (the "bike farmer") would travel completely by bike-moving from one yard to another to maintain the sites and deliver the harvest [83]. Another business opportunity has arisen from the need for consulting services and labor for residents who are interested in producing food in their own yards, but lack the necessary skills or resources [84]. Clearly, residential parcels offer a great alternative for expanding urban agriculture; although individually they are small, when considered together, they are among the largest contributors to urban green space [85].

\subsection{Built Structures}

Sustainable land use planning must also consider the built infrastructure, including buildings themselves, and urban agriculture offers unique opportunities to incorporate production functions in unexpected places. From a more visionary perspective, prototype projects have been developed to integrate intensive farming into multi-use, multi-level urban structures. Architect Vincent Callbaut developed a prototype building to integrate intensive farming with other urban spaces including housing, offices, and laboratories. The architectural system, inspired by the biological structure of a dragonfly, is designed to accommodate agriculture on several levels through kitchen gardens, orchards, suspended fields, and other vegetated features. This ecological design also considers the reuse of biodegradable waste and energy conservation [86]. Detailed images of this design and others incorporating urban agriculture can be found at the designer's website, http://vincent.callebaut.org/. The Vertical Farm Project accepts design entrees that integrate food production into high-rise buildings and offers a web-based forum for presenting the designs and related concepts (http://verticalfarm.com).

While the futuristic prototypes offer inspiration for architectural design, many opportunities exist to retrofit existing buildings with the appropriate infrastructure to support food production. The large number of flat rooftops in many cities such as Chicago could serve as a platform for urban agriculture. Green roofs, which are specifically designed or retrofitted to buildings to hold growing media, allow drainage, and support plant life, can be used for edible plants (Figure 3). Because of the harsh conditions plants are exposed to on rooftops (i.e., wind exposure, drought, and extreme temperature fluctuations), the planting palette would be limited to tolerant species such as herbs. Easy access to the site for maintenance and harvesting is also an important consideration with edible green roofs. Flat rooftops might also be adapted to hold greenhouses that use either soil or hydroponic production methods to grow plants [87]. Alternatively, simple structures such as livestock troughs or "kiddie" pools can be used as the containers in which to grow vegetables on an impermeable rooftop [88]. 
Figure 3. Public education at the Noble Rot rooftop garden in Portland, OR. (a) In the words of urban farmer, Marc Boucher-Colbert of Urban Agriculture Solutions, LLC. (b) Marc setting up the garden beds, (c) Vegetables growing in rooftop beds, (d) Marc preparing the rooftop garden for edible plantings.

(a) "The Noble Rot rooftop garden grows a wide variety of vegetables and flowers featured in dishes at a top West Coast wine bar just ten feet below its deck. In this highly experimental growing space after four seasons of cultivation, ideas about rooftop gardening still sprout as fast as a summer planting of arugula (Eruca sativa). Some concepts naturalize, while others are composted after a season's trial. The garden has developed as a close partnership between me and Leather Storrs (chef and restaurant co-owner). The garden's design was contemporaneous with the building's construction, and so began with 6 large beds built over the building's north wall and with an 'ediblizing' of the platinum LEED building's eco-roof. Since that space was almost immediately overflowing with edible greenery, the garden has spread over almost the entire building's 30'x 70' roof. Children's wading pools provided the means to trial low-weight growing beds (approximately $20 \mathrm{lbs}$. per square foot), and after proving their success they were replaced for the 2010 season with wooden-sided raised beds lined with a potable-water certified liner. The garden provides food year-round, but the bulk of its output occurs between April and October, when the restaurant is sometimes hard-pressed to keep up with its harvest. Occasionally, chef Leather sells surplus produce to other restaurants, but for the most part everything grown upstairs finds its way either into a signature salad or special dish. In addition to my work on the project, one additional gardener assists with the garden tasks, and chefs are constantly up and down cutting produce that by definition could not be any fresher." Marc Boucher-Colbert, Urban Agriculture Solutions LLC.
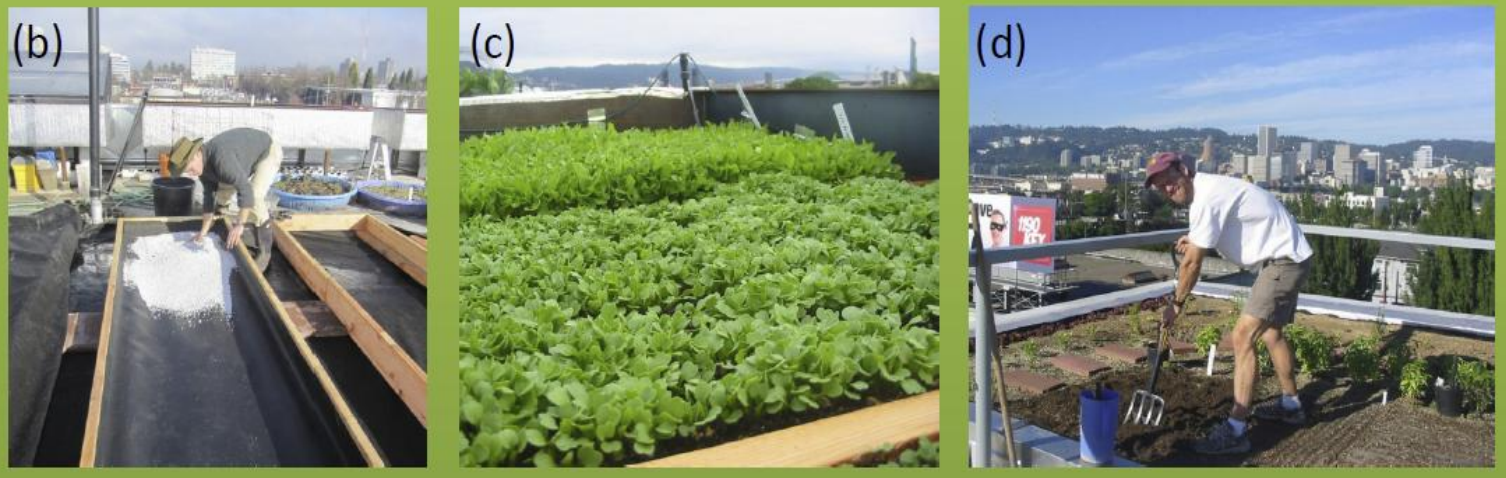

Photos by Marc Boucher-Colbert

\section{Constraints and Barriers to Urban Agriculture}

While the opportunities to use urban agriculture as a sustainable land use strategy are vast, and many successful examples exist across the U.S., several issues continue to arise as new enterprises develop. One of the greatest constraints to the widespread adoption of urban agriculture is the limited access to land for those who would like to grow food, and the lack of secure of tenure on that land, particularly where the production functions are competing with other uses (such as commercial development) that provide greater profit for the landowner [19]. For example, many community gardens are established on vacant lots or other underutilized spaces, but without the direct permission or long-term commitment of the land owner or manager. Marginalized groups and minority populations are particularly vulnerable to the problem of land access and security, since they often do not have the means to purchase land [19,89]. At that same time, these groups typically have the greatest need and available labor pool to produce healthy food. This is another reason to offer more of the publicly-owned open space (e.g., parks, schoolyards, etc.) for community gardens [48] and to integrate urban agriculture directly into the planning of green infrastructure in cities. 
Another barrier to urban agriculture is the limited availability of land that is actually suitable for producing food based on the location, size, and access to necessary resources. Land use inventories and land suitability analysis have been used to identify appropriate locations based primarily on biophysical factors [65]. Solar access for an existing site is an important factor, since most edible plants have a relatively high sunlight requirement, but the future access to sunlight (depending on new construction and growth of trees) should be considered [90]. Water is also a consideration, as most plants will require irrigation at some period during the growing season, and running water is often used to clean fruits and vegetables on site. An appropriate growing media, typically soil, is an important resource for growing plants. While the ideal site would offer a rich soil that is high in nutrients and organic matter, many urban agriculture projects are established on poor soils, or even impervious surfaces, often by building raised beds and hauling in the necessary soil and amendments. Other considerations for the site include: protection from vandalism and theft, access for gardeners, proximity to markets, and aesthetics of the neighborhood [22].

The successful integration of urban agriculture into the complex ecosystem of a city requires planning beyond the production sites themselves. Insufficient infrastructure and supportive services for the entire food system can severely limit the widespread adoption of these systems [2]. Consideration must be given to the market connections, transportation systems, resource availability, and waste disposal systems. For example, more information is needed to understand the quantity, quality, availability, and location of organic waste products in the urban environment, as well as the extent to which waste products might contribute to the fertility needs of urban agriculture [27]. Urban planners should be involved in these and other land use issues related to the food systems, in order to improve efficiencies and performance [42]. Another issue requiring the involvement of planners is the potential for sprawl or expansion of urban development, when tracts of green space and farmland are retained within the urban boundaries for producing food [59]. The approaches to this issue would not be unlike the conservation of other types of green space in the city.

The primary constraint related to urban planning for agriculture in the US, however, is probably the intense competition from other land uses. While urban agriculture offers multiple functions for open space, many residents prefer other uses, such as "nature" parks or sports fields, that are oriented more toward cultural functions. One argument against urban agriculture, particularly with allotment-style community gardens, is that these spaces offer a greater benefit to individual residents (the gardeners) than they do to the public-at-large [48]. The issue is further complicated by the fact that various socioeconomic or demographic groups value functions differently [61]. In the literature, urban agriculture is rarely compared to other alternatives for open space, because of the complexity in evaluating systems across multiple functions, including production of food and other materials. Even focusing simply on recreational functions can be quite difficult, due to the complications in assessing how agricultural areas are used (or how "recreation" is defined) [91]. The comparison of urban agriculture to other alternatives for open space is certainly an important area for future research, but these efforts will require comprehensive assessment strategies, such as the valuation of ecosystem services ("benefits people obtain from ecosystems") [92]. A framework that evaluates overall landscape performance is necessary to make these comparisons [4]. By considering the multifunctionality of urban agriculture, the argument for this land use being a desirable alternative (even when compared with competitive uses) is much stronger. 
Along with the barriers related to planning, the perceived and actual health risks of growing food in an urban environment must be considered, and there is currently a dearth of research on human health issues [27]. For most cities in the U.S., however, the perceived risks are probably greater than the real risks. While food safety has been a concern, primarily related to the potential for plants to uptake heavy metals or other toxins from contaminated soils or irrigation water sources, several studies have demonstrated that the risks are probably minor compared with the human health benefits from the improved nutrition, increased exercise, and improved psychological state from growing food in urban areas $[41,93,94]$. In a study of the health risk of 28 different sites used for urban agriculture, Bramwell et al. found that even where soil samples contained lead and arsenic, the bioaccessibility of the contaminants was low, indicating vegetables were not accumulating the materials [95]. To reduce the health risks where soil contamination is a concern, the agricultural system can be adapted in several ways, by: (1) growing crops for non-edible products (e.g., Christmas trees or cut flowers), (2) selecting plants that do not accumulate metals in their edible parts (i.e., many fruit-bearing crops), and (3) establishing plants in raised beds above the contaminated soil. Another concern is the possibility of pathogen contamination resulting from irrigating with contaminated water sources or improper use of manure and compost products. These issues are not particularly greater in the urban environment than in rural agricultural systems, and they can typically be managed through education.

Finally, the expansion of urban agriculture is limited by the lack of basic skills of many urban residents who have little previous experience with these activities. The skills necessary for urban agriculture include not only those related to the design and management of the production systems themselves, but also skills to coordinate resource use, manage the laborers, market the products, organize the transportation, and balance the financial profile of the business. The knowledge and skills necessary to manage these systems for multiple functions becomes even more complex, requiring expertise in ecological, social, and cultural dimensions.

\section{Discussion}

To summarize, this paper explores the possibility of urban agriculture as a sustainable and multifunctional land use option for cities in the United States. While the literature includes many different studies that have documented the wide range of functions provided by urban agriculture, these systems have been somewhat neglected in urban planning in the U.S., rarely receiving the same level of attention and protection as other competing land uses. The precedents for multifunctional urban agriculture can be found around the world, dating back thousands of years. The documented history of urban agriculture in the U.S. goes back approximately a century, beginning with community gardens established on vacant lots in several large cities. Today, a primary focus of urban agriculture in the U.S. is to improve food security for communities that do not have access to fresh, healthy food. Urban agriculture can be integrated in many different forms and at many different scales, from a small urban garden to efforts that extend across an entire city. While a great number of opportunities exist to incorporate urban agriculture at every scale, some barriers do exist including: limited access to suitable land, lack of secure tenure on the property, insufficient infrastructure and supportive services, competition with other uses for open space, perceived and actual human health risks of growing food in the urban environment, and extensive skills necessary to manage a multifunctional urban agriculture 
system. Many of these barriers, however, might be overcome by focusing research efforts in this direction and by educating the public about the wide range of benefits from urban agricultural systems.

Urban agriculture offers unique research opportunities that require alternative methodological approaches. Participatory research can be very effective for gathering data, while at the same time engaging and informing the public. For example, local residents might become involved in the mapping and inventory of green spaces that could be used for food production [96]. The urban agriculture gardeners/farmers themselves could be involved in the data collection by documenting their activities, tracking their inputs and yields, inventorying the plants, and spatial mapping of the garden site [72]. Other studies have engaged residents or gardener/farmers in focus groups to determine factors most important for protecting and expanding urban agriculture [97]. Redwood suggests that participatory approaches for urban agriculture research should consider the following questions: (1) "Who is growing what and why?"; (2) "How are the interests of the local people reflected by the research?"; (3) "What are the economic factors influencing decisions?"; and (4) "What institutions are involved and in what capacity?" [19].

One important research opportunity is in assessing the suitability of urban land for agricultural functions based on factors such as soil type, solar access, and proximities to necessary markets and resources. Spatial analysis in Geographic Information Systems (GIS), which has been used to map green infrastructure and extend green networks [98], could offer useful applications for assessing and expanding urban agriculture [26]. Asset mapping, which is a multi-stakeholder process for action planning and policy design, can be used to describe the physical characteristics of a study site using GIS data including land use land cover (LULC) [59]. Using the results of suitability analysis, land use inventories can be developed to map the suitable land to help increase institutional awareness and political support for urban agriculture [65]. The opportunity also exists to engage the public in the inventory process, by allowing residents to map the available spaces within their own neighborhoods.

Another area of research on urban agriculture systems is in evaluating the impacts of agricultural systems on the planning and sustainability of the urban environment. A great need exists for more studies that deeply analyze the contribution of urban agriculture to sustainability. Some work is underway in assessing the sustainability of individual projects or farms, but a focus on larger scales (neighborhood, city, or region) would make an important contribution to the literature. This research could be a comparative analysis of cities where urban agriculture is an extensive land use, versus cities with similar characteristics, but with limited urban agriculture. In addition, planning research could allow the evaluation of future landscape alternatives that integrate food systems into cities. Land use models are effective in representing these alternatives and comparing them based on various indicators of sustainability selected by experts and/or stakeholders $[99,100]$. This approach can also inspire and inform decision-makers of the opportunities and impacts of different alternatives [101]. Ericksen et al. suggest the best scenarios related to food systems would be developed interactively with stakeholders to build shared understand among diverse perspectives and explore risky management options [102].

If urban agriculture is to become a highly accepted alternative for future land use planning, much more work is needed to develop a better understanding of the relationship between urban agriculture and human health. In regard to the issue of the safety of growing food in contaminated soils or irrigating with contaminated water, most studies suggest that the benefits often outweigh the risks, as described earlier. However, several studies have demonstrated unacceptable uptake levels of lead [103] 
and other heavy metals [104] in some vegetables grown in soils with excessive concentrations of these contaminants. Certainly, much more research is needed to fully understand the differential uptake of toxins by various crops under a wide range of growing conditions (climate, weather, soil type, etc.). This information can then be incorporated into a global database that would be accessible to gardeners/farmers. Along with food safety, another health consideration is the contribution of urban agriculture to human nutrition. Wilkins suggests dietetic professionals are becoming more involved in food systems and sustainable agriculture issues, leading to the emergence of "civic dietetics" [105]. Great opportunities exist to use urban agriculture to combat childhood obesity in particular, since these systems can engage children through a holistic approach that could encourage healthy eating and increased physical activity in gardening.

This review of multifunctional urban agriculture as a sustainable land use alternative has implications for urban planners, landscape designers, and extension agents. For urban planners, the review offers a justification for planning agricultural activities into the urban environment, based on more than the production benefits alone. Urban agriculture is compatible with many other goals for sustainability, primarily by balancing inputs and outputs, reusing waste products, reducing energy use, and optimizing green infrastructure. The successful strategies described in the paper can be used as examples to help persuade communities and decision-makers to preserve existing agricultural land and expand agriculture in some areas. Landscape designers might be inspired by the wealth of opportunities to integrate production functions into the designs of landscapes at nearly every scale - from a continuous greenway system throughout an entire city, to a small backyard (or frontyard) garden bed with edible plants in an ornamental pattern. If urban agriculture efforts continue to expand, landscape designers can be involved in developing multifunctional alternatives for community farms and gardens that offer many benefits. Extension agents, who have focused primarily on agriculture in rural areas, or ornamental plantings in urban areas, might see opportunities to bring these together. They could translate the available research on food crop production, greenhouse management, composting, and gardening into valuable materials for urban agriculturalists.

\section{Conclusions}

Sustainable land use is of critical importance as we consider how to balance the needs of a growing population with the desire to protect our natural resources and environment. Mougeot suggests that urban agriculture "... must be viewed not as a problem but as one tool contributing to sustainable urban development" ([1]; p. 10). Indeed, the ecological footprint of a city is greatly impacted by the food system (production practices, transportation distances, energy inputs, and management of organic waste products), and urban agriculture could play a much greater role in improving all of these factors. Because the concept of sustainability has become an important framework for urban planning, a logical approach is to promote urban agriculture and local food systems using this framework. Most urban agriculture activities have been established through grass-roots efforts that inspire change on a larger scale (bottom-up approach), but we now have enough evidence of benefits of urban agriculture, that this land use might be incorporated into planning and policies at all levels. Top-down efforts might work best to improve the coordination of urban agriculture activities and to maximize the multifunctional benefits. 
To be a viable alternative in cities and compete with other land uses, the justification for urban agriculture must include the ecological and cultural functions these systems offer, in addition to the direct benefits of food produced. New strategies and related policies are needed to support urban agriculture, such as requiring a certain proportion of public green be designated as community gardens, so anyone committed to producing their own food could have access to a plot of land on which to do it. Urban agriculture might also be considered as an alternative or a supplement to existing public welfare or nutrition assistance programs. Engaging low-income families in the production of their own food could improve their sense of empowerment, their understanding of food and nutrition, and their skills in horticulture and gardening. Another option is to redirect some of the governmental funding that subsidizes commodity production systems, to instead help support the production of healthy, diversified systems which provide multiple functions. Investments in urban agriculture should be included as part of the U.S. economic recovery program — offering new jobs in agriculture, investing in local economies, and revitalizing urban communities. While urban agriculture alone cannot solve all of the problems we face today, this land use is certainly one of the more compelling and attainable strategies for improving a complex urban ecosystem.

\section{Acknowledgements}

The author would like to thank S'ra DeSantis and Marc Boucher-Colbert for their contributions in the figures, and Daniel Erickson and Felix Wai for reviewing an earlier version of this paper.

\section{References and Notes}

1. Mougeot, L.J.A. Growing Better Cities: Urban Agriculture for Sustainable Development; International Development Research Centre: Ottawa, ON, Canada, 2006; p. 97.

2. Deelstra, T.; Girardet, H. Urban agriculture and sustainable cities. In Growing Cities, Growing Food: Urban Agriculture on the Policy Agenday; Bakker, N., Dubbeling, M., Gundel, S., Sabel-Koschela, U., de Zeeuw, H., Eds.; Deutsche Stiftung fur Internationale Entwicklung (DSE): Feldafing, Germany, 2000; pp. 43-65.

3. Vitiello, D. Growing edible cities. In Growing Greener Cities; Birch, E.L., Wachter, S.M., Eds.; University of Pennsylvania Press: Philadelphia, PA, USA, 2008.

4. Lovell, S.T.; Johnston, D.M. Designing landscapes for performance based on emerging principles in landscape ecology. Ecol. Soc. 2009, 14, 44.

5. Holmes, J. Impulses towards a multifunctional transition in rural Australia: Gaps in the research agenda. J. Rural Stud. 2006, 22, 142-160.

6. Oostindie, H.; Roep, D.; Renting, H. Definitions, references and interpretations of the concept of multifunctionality in The Netherlands. Eur. Ser. Multifunct. 2006, 10, 41-81.

7. Lovell, S.T.; Johnston, D.M. Creating multifunctional landscapes: How can the field of ecology inform the design of the landscape? Front. Ecol. Environ. 2009, 7, 212-220.

8. Heilig, G. Multifunctionality of landscape and ecosystem services with respect to rural development. In Sustainable Development of Multifunctional Landscapes; Helming, K., Wiggering, H., Eds.; Springer: Berlin, Germany, 2003. 
9. Wilson, G.A. From 'weak' to 'strong' multifunctionality: Conceptualising farm-level multifunctional transitional pathways. J. Rural Stud. 2008, 24, 367-383.

10. Wilson, G.A. Multifunctional Agriculture-A Transition Theory Perspective; CABI: Oxfordshire, UK, 2007.

11. Deelstra, T.; Boyd, D.; van den Biggelaar, M. Multifunctional land use-An opportunity for promoting urban agriculture in Europe. Urban Agric. Mag. 2001, 4, 33-35.

12. Yokohari, M. Urban agro-activities in Asian mega-cities. In Proceedings of the IALE 2007 World Congress-25 Years of Landscape Ecology: Scientific Principles in Practice, Wageningen, The Netherlands, 8-12 July 2007; Bunce, R.G.H., Jongman, R.H.G., Hojas, L., Weel, S., Eds.; International Association for Landscape Ecology (IALE): Wageningen, The Netherlands, 2007.

13. Shellhorn, N.A.; Macfadyen, S.; Bianchi, F.J.J.A.; Williams, D.G.; Zalucki, M.P. Managing ecosystem services in broadacre landscapes: What are the appropriate spatial scales? Aust. J. Exp. Agric. 2008, 48, 1549-1559.

14. Hough, M. Cities and Natural Process: A Basis for Sustainability, 2nd ed.; Routledge: New York, NY, USA, 2004; p. 292.

15. Knickel, K.; Renting, H. Methodological and conceptual issues in the study of multifunctionality and rural development. Sociol. Ruralis. 2002, 40, 512-528.

16. Lovell, S.T.; DeSantis, S.; Nathan, C.A.; Olson, M.B.; Mendez, V.E.; Kominami, H.C.; Erickson, D.L.; Morris, K.S.; Morris, W.B. Integrating agroecology and landscape multifunctionality in Vermont: An evolving framework to evaluate the design of agroecosystems. Agr. Syst. 2010, 103, 327-341.

17. Foeken, D.W.J.; Owuor, S.O. Farming as a livelihood source for the urban poor of Nakuru, Kenya. Geoforum 2008, 39, 1978-1990.

18. Whelan, A.; Wrigley, N.; Warm, D.; Cannings, E. Life in a 'food desert'. Urban Stud. 2002, 39, 2083-2100.

19. Redwood, M. Agriculture in Urban Planning-Generating Livelihoods and Food Security; Earthscan: London, UK, 2009.

20. Motsenbocker, C.E. Urban agriculture: The role of horticulture in the city. Hortscience 2009, 44, 995-996.

21. Brown, K.H.; Carter, A. Urban Agriculture and Community Food Security in the United States: Farming from the City Center to the Urban Fringe; Urban Agriculture Committee of the Community Food Security Coalition: Portland, OR, USA, February 2003.

22. Bhatt, V.; Farah, L.M. Designing edible landscapes. Open House Int. 2009, 34, 5-7.

23. McLaughlin, L. Inner-city farms. Time Magazine, 24 July 2008.

24. Bohn, K.; Viljoen, A. More space with less space: An urban design strategy. In CPULS: Continuous Productive Urban Landscapes-Designing Urban Agriculture for Sustainable Cities; Viljoen, A., Ed.; Elsevier: Amsterdam, The Netherlands, 2005; pp. 11-16.

25. Goddard, M. Urban greywater reuse at the D'LUX Development. Desalination 2006, 188, $135-140$. 
26. Holmer, R.J.; Drescher, A.W. Allotment gardens of Cagayan de Oro: Their contribution to food security and urban environmental management. In Urban and Peri-Urban Developments-Structures, Processes and Solutions; Knie, C., Ed.; Southeast Asian-German Summer School Program: Cologne, Germany, 2005; pp. 149-155.

27. Midmore, D.J.; Jansen, H.G.P. Supplying vegetables to Asian cities: Is there a case for peri-urban production? Food Policy 2003, 28, 13-27.

28. Bernholt, H.; Kehlenbeck, K.; Gebauer, J.; Buerkert, A. Plant species richness and diversity in urban and peri-urban gardens of Niamey, Niger. Agroforest. Syst. 2009, 77, 159-179.

29. Dubbeling, M.; Bracalenti, L.; Lagorio, L. Participatory design of public spaces for urban agriculture, Rosario, Argentina. Open House Int. 2009, 34, 36-49.

30. Koont, S. The urban agriculture of Havana. Mon. Rev. 2009, 60, 44-63.

31. Smardon, R.C. Perception and aesthetics of the urban environment-Review of the role of vegetation. Landscape Urban Plan. 1988, 15, 85-106.

32. East, A.J.; Dawes, L.A. Homegardening as a panacea: A case study of South Tarawa. Asia Pac. Viewp. 2009, 50, 338-352.

33. Alaimo, K.; Packnett, E.; Miles, R.A.; Kruger, D.J. Fruit and vegetable intake among urban community gardeners. J. Nutr. Educ. Behav. 2008, 40, 94-101.

34. Parmer, S.M.; Salisbury-Glennon, J.; Shannon, D.; Struempler, B. School gardens: An experiential learning approach for a nutrition education program to increase fruit and vegetable knowledge, preference, and consumption among second-grade students. J. Nutr. Educ. Behav. 2009, 41, 212-217.

35. Wakefield, S.; Yeudall, F.; Taron, C.; Reynolds, J.; Skinner, A. Growing urban health: Community gardening in South-East Toronto. Health Promot. Int. 2007, 22, 92-101.

36. Shinew, K.J.; Glover, T.D.; Parry, D.C. Leisure spaces as potential sites for interracial interaction: Community gardens in urban areas. J. Leisure Res. 2004, 36, 336-355.

37. Ferris, J.; Norman, C.; Sempik, J. People, land and sustainability: Community gardens and the social dimension of sustainable development. Soc. Policy Admin. 2001, 35, 559-568.

38. Reid, D. Community gardens and food security. Open House Int. 2009, 34, 91-95.

39. Neustrom, E.K.; Motsenbocker, C.E. Urban youth: Effects of a summer agriculture, cooking, and nutrition program. Hortscience 2009, 44, 1047.

40. Lautenschlager, L.; Smith, C. Beliefs, knowledge, and values held by inner-city youth about gardening, nutrition, and cooking. Agr. Hum. Values 2007, 24, 245-258.

41. Somerset, S.; Bossard, A. Variations in prevalence and conduct of school food gardens in tropical and subtropical regions of north-eastern Australia. Public Health Nutr. 2009, 12, 1485-1493.

42. Pothukuchi, K.; Kaufman, J.L. The food system-A stranger to the planning field. J. Am. Plann. Assoc. 2000, 66, 113-124.

43. Mubvami, T.; Mushamba, S.; de Zeeuw, H. Integration of agriculture in urban land use planning. In Cities Farming for the Future-Urban Agriculture for Green and Productive Cities; van Veenhuizen, R., Ed.; International Development Research Centre, RUAF Foundation: Leusden, The Netherlands, 2006; Available online: www.idrc.ca/en/ev-103759-201-1-DO_ TOPIC.html (accessed on 19 July 2010). 
44. Land Use Planning; RUAF Foundation: Leusden, The Netherlands, 2006; Available online: www.ruaf.org/node/344 (accessed on 25 March 2010).

45. Cassidy, A.; Patterson, B. A Planner's Guide to the Urban Food System; Post Carbon Institute: Portland, OR, USA, 2008; Available online: http://postcarboncities.net/files/ PlannersGuidetotheFoodSystem.pdf (accessed on 19 July 2010).

46. Pothukuchi, K. Community food assessment-A first step in planning for community food security. J. Plan. Educ. Res. 2004, 23, 356-377.

47. American Planning Association Policy Guide on Community and Regional Food Planning; American Planning Association: Chicago, IL, USA, 2007; Available online: www.planning.org/ policy/guides/adopted/food.htm (accessed 19 July 2010).

48. Hou, J.; Johnson, J.M.; Lawson, L.J. Greening Cities, Growing Communities: Learning from Seattle's Urban Community Gardens; University of Washington Press: Seattle, WA, USA, 2009.

49. Ericksen, P.J. Conceptualizing food systems for global environmental change research. Global Environ. Chang. 2008, 18, 234-245.

50. Kumar, B.M.; Nair, P.K.R. The enigma of tropical homegardens. Agroforest. Sys. 2004, 61, $135-152$.

51. Eichemberg, M.T.; Amorozo, M.C.D.; de Moura, L.C. Species composition and plant use in old urban homegardens in Rio Claro, Southeast of Brazil. Acta Bot. Bras. 2009, 23, 1057-1075.

52. Méndez, V.E. An assessment of tropical homegardens as examples of local sustainable agroforestry systems. In Agroecosystem Sustainability: Developing Practical Strategies; Gliessman, S.R., Ed.; CRC Press: Boca Raton, FL, USA, 2000; pp. 51-66.

53. O'Brien, S. Kitchen gardens: Sowing the seeds. Libr. J. 2001, 126, 81-84.

54. Smit, J. Community-based urban agriculture as a history and future. In Proceedings of the Symposium on Urban Agriculture: Emerging Opportunities in Science, Education, and Policy, Dallas, TX, USA, 19-22 May 2002; pp. 83-89.

55. Mougeot, L.J.A. Agropolis: The Social, Political and Environmental Dimensions of Urban Agriculture; International Development Research Center: Ottawa, ON, Canada, 2005; p. 286.

56. Parrot, L.; Sotamenou, J.; Kamgnia, B.D.; Nantchouang, A. Determinants of domestic waste input use in urban agriculture lowland systems in Africa: The case of Yaounde in Cameroon. Habitat Int. 2009, 33, 357-364.

57. Madaleno, I. Urban agriculture in Belem, Brazil. Cities 2000, 17, 73-77.

58. Viljoen, A.; Bohn, K. Continuous productive urban landscape (CPUL): Essential infrastructure and edible ornament. Open House Int. 2009, 34, 50-60.

59. Zhang, F.F.; Cai, J.M.; Liu, G. How urban agriculture is reshaping peri-urban Beijing? Open House Int. 2009, 34, 15-24.

60. Girardet, H. Urban agriculture and sustainable urban development. In CPULS: Continuous Productive Urban Landscapes-Designing Urban Agriculture for Sustainable Cities; Viljoen, A., Ed.; Elsevier: Amsterdam, The Netherlands, 2005; pp. 32-39.

61. Domene, E.; Sauri, D. Urbanization and class-produced natures: Vegetable gardens in the Barcelona Metropolitan Region. Geoforum 2007, 38, 287-298.

62. van Leeuwen, E.; Nijkamp, P.; Vaz, T.D. The multifunctional use of urban greenspace. Int. J. Agric. Sustain. 2010, 8, 20-25. 
63. Lawson, L.J. City Bountiful: A Century of Community Gardening in America; University of California Press: Berkeley, CA, USA, 2005.

64. Viljoen, A.; Bohn, K.; Howe, J. CPULS: Continuous Productive Urban Landscapes-Designing Urban Agriculture for Sustainable Cities; Elsevier: Amsterdam, The Netherlands, 2005; p. 304.

65. Mendes, W.; Balmer, K.; Kaethler, T.; Rhoads, A. Using land inventories to plan for urban agriculture experiences from Portland and Vancouver. J. Am. Plann. Assoc. 2008, 74, 435-449.

66. Local Food, Farms \& Jobs-Growing the Illinois Economy; Illinois Local and Organic Food and Farm Task Force: Springfield, IL, USA, 2009; Available online: www.agr.state.il.us/newsrels/ taskforcereport-outside.pdf (accessed on 17 July 2010).

67. Van der Ryn, S. The suburban context. In Sustainable Communities: A New Design Synthesis for Cities, Suburbs and Towns; van der Ryn, S., Calthorpe, P., Eds.; New Catalyst Books: Gabriola Island, BC, Canada, 1986.

68. House, G. Retrofitting suburban landscapes with sustainable agroecosystems. In Sustainable Agroecosystem Management; Bohlen, P.J.; House, G., Eds.; CRC Press: Boca Raton, FL, USA, 2009; pp. 283-296.

69. DeJesus, C.R. Pedro Albizu Campos High School (PACHS), Chicago, IL, USA. Personal communication, April 2010.

70. Gorham, M.R.; Waliczek, T.M.; Snelgrove, A.; Zajicek, J.M. The impact of community gardens on numbers of property crimes in urban Houston. HortTechnology 2009, 19, 291-296.

71. Baker, L.E. Tending cultural landscapes and food citizenship in Toronto's community gardens. Geogr. Rev. 2004, 94, 305-325.

72. Airriess, C.A.; Clawson, D.L. Vietnamese market gardens in New Orleans. Geogr. Rev. 1994, 84, $16-31$.

73. Imbruce, V. Bringing Southeast Asia to the Southeast United States: New forms of alternative agriculture in Homestead, Florida. Agric. Human Values 2007, 24, 41-59.

74. Bachmann, J. Market Gardening: A Startup Guide; NCAT: Butte, MT, USA, 2009; pp. 1-20.

75. Filipic, M. Farms near urban areas adopt varying strategies to survive, thrive. Available online: http://extension.osu.edu/ news/story.php?id=5312 (accessed on 17 July 2010).

76. Christensen, R. SPIN farming: Improving revenues on sub-acre plots. Urban Agriculture Magazine, 25-26 December 2007.

77. Hagy, R. Landscaping with Fruits and Vegetables; The Overlook Press: Woodstock, NY, USA, 1990.

78. Flores, H.C. Food Not Lawns—How to Turn Your Yard into a Garden and Your Neighborhood into a Community; Chelsea Green Publishing Company: White River Junction, VT, USA, 2006; p. 334.

79. Jacke, D.; Toensmeier, E. Design and practice. In Edible Forest Gardens; Chelsea Green: White River Junction, VT, USA, 2005; Volume 2, p. 655.

80. Haeg, F. Edible Estates: Attack on the Front Lawn; Metropolis Books: New York, NY, USA, 2008; p. 127.

81. Coleman, P.A. The front lawn farm. Portland Mercury, 13 August 2009.

82. Westervelt, A. A business case for backyard farms. Sustainable Industries Magazine, 2 July 2008.

83. Minervini, J. The bike farmer. Willamette Week, 20 February 2008. 
84. Griffin, A.; Milholland, L. Urban agrarians - Is that a farm in your backyard? Edible Portland, Spring 2008; Available online: http://www.edibleportland.com/2008/04/urban_agrarians.html (accessed on 17 July 2010).

85. Smith, R.M.; Gaston, K.J.; Warren, P.H.; Thompson, K. Urban domestic gardens (V): Relationships between landcover composition, housing and landscape. Landscape Ecol. 2005, 20, 235-253.

86. Callebaut, V. Dragonfly, a metabolic farm for urban agriculture. Space 2009, 499, 42-45.

87. Wilson, A. Growing food locally: Integrating agriculture into the built environment. Environmental Building News, 1 February 2009; Available online: www.buildinggreen.com/auth/ article.cfm/2009/1/29/Growing-Food-Locally-Integrating-Agriculture-Into-the-BuiltEnvironment (accessed on 17 July 2010).

88. Pokorny, K. Gardens that rose to the top in 2007. The Oregonian, 12 January 2008.

89. Poor, P.J.; Brule, R. An investigation of the socio-economic aspects of open space and agricultural land preservation. J. Sustain. Agr. 2007, 30, 165-176.

90. DeKay, M. The implications of community gardening for land use and density. J. Archit. Plan. Res. 1997, 14, 126-149.

91. Schipperijn, J.; Ekholm, O.; Stigsdotter, U.K.; Toftager, M.; Bentsen, P.; Kamper-Jorgensen, F.; Randrup, T.B. Factors influencing the use of green space: Results from a Danish national representative survey. Landscape Urban Plan. 2010, 95, 130-137.

92. Millennium Ecosystem Assessment. Ecosystems and Human Well-Being: Synthesis; Island Press: Washington, DC, USA, 2005.

93. Leake, J.R.; Adam-Bradford, A.; Rigby, J.E. Health benefits of 'grow your own' food in urban areas: Implications for contaminated land risk assessment and risk management? Environ. Health 2009, 8(Suppl 1), S6.

94. Doucette, W.J.; Chard, J.K.; Fabrizius, H.; Crouch, C.; Petersen, M.R.; Carlsen, T.E.; Chard, B.K.; Gorder, K. Trichloroethylene uptake into fruits and vegetables: Three-year field monitoring study. Environ. Sci. Technol. 2007, 41, 2505-2509.

95. Bramwell, L.; Pless-Mulloli, T.; Hartley, P. Health risk assessment of urban agriculture sites using vegetable uptake and bioaccessibility date-An overview of 28 sites with a combined area of 48 hectares. Epidemiology 2008, 19 (Suppl), S150.

96. Fraser, E.D.G. Urban ecology in Bangkok, Thailand: Community participation, urban agriculture and forestry. Environments 2002, 30, 37-50.

97. Thapa, R.B.; Murayama, Y. Land evaluation for peri-urban agriculture using analytical hierarchical process and geographic information system techniques: A case study of Hanoi. Land Use Policy 2008, 25, 225-239.

98. Wickham, J.D.; Riitters, K.H.; Wade, T.G.; Vogt, P. A national assessment of green infrastructure and change for the conterminous United States using morphological image processing.

Landscape Urban Plan 2010, 94, 186-195.

99. Tress, B.; Tress, G. Scenario visualisation for participatory landscape planning-A study from Denmark. Landscape Urban Plan. 2003, 64, 161-178. 
100. Walz, A.; Lardelli, C.; Behrendt, H.; Gret-Regamey, A.; Lundstrom, C.; Kytzia, S.; Bebi, P. Participatory scenario analysis for integrated regional modelling. Landscape Urban Plan. 2007, 81, 114-131.

101. Santelmann, M.V.; White, D.; Freemark, K.; Nassauer, J.I.; Eilers, J.M.; Vache, K.B.; Danielson, B.J.; Corry, R.C.; Clark, M.E.; Polasky, S.; Cruse, R.M.; Sifneos, J.; Rustigian, H.; Coiner, C.; Wu, J.; Debinski, D. Assessing alternative futures for agriculture in Iowa, USA. Landscape Ecol. 2004, 19, 357-374.

102. Ericksen, P.J.; Ingram, J.S.I.; Liverman, D.M. Food security and global environmental change: Emerging challenges. Environ. Sci. Policy 2009, 12, 373-377.

103. Finster, M.E.; Gray, K.A.; Binns, H.J. Lead levels of edibles grown in contaminated residential soils: A field survey. Sci. Total Environ. 2004, 320, 245-257.

104. Kachenko, A.G.; Singh, B. Heavy metals contamination in vegetables grown in urban and metal smelter contaminated sites in Australia. Water Air Soil Poll. 2006, 169, 101-123.

105. Wilkins, J.L. Civic dietetics: Opportunities for integrating civic agriculture concepts into dietetic practice. Agric. Human Values 2009, 26, 57-66.

(C) 2010 by the authors; licensee MDPI, Basel, Switzerland. This article is an Open Access article distributed under the terms and conditions of the Creative Commons Attribution license (http://creativecommons.org/licenses/by/3.0/). 